\title{
Visual Scoring of Ruminant Body Condition: Trapped in Inaccuracy
}

\author{
Akbar Nikkhah" \\ Department of Animal Sciences, Faculty of Agricultural Sciences, University of Zanjan, National Elite Foundation, Iran \\ *Corresponding author: Akbar Nikkhah, Chief Highly Distinguished Professor, Department of Animal Sciences, Faculty of Agricultural Sciences, University of Zanjan, \\ Foremost Principal Highly Distinguished Elite-Generating Scientist, National Elite Foundation, Iran, Tel: 0098-2412801; E-mail: anikkha@yahoo.com
}

Rec date: Jul 27, 2015; Acc date: Jul 28, 2015; Pub date: Jul 29, 2015

Copyright: (C) 2015 Nikkhah A. This is an open-access article distributed under the terms of the Creative Commons Attribution License, which permits unrestricted use, distribution, and reproduction in any medium, provided the original author and source are credited.

\begin{abstract}
This perspective article raises a global concern on accuracy of body condition scoring (BCS) of ruminants based on visual observations of external fat depts. Recent evidence suggests that low body condition score in a visually and apparently thin animal does not accurately indicated that the animal is truly thin. Visually think looking ruminants may have considerable amount of visceral or abdominal adipose tissues that significantly contribute to hepatic import of fats and unhealthy substrates. Body condition score as a visual indicator of external and subcutaneous ruminant adiposity cannot be relied on accurately to be utilized in effective metabolic management of high-producing dairy and beef ruminants.
\end{abstract}

Keywords: Body condition score; External fat; Visceral adipose tissue; Ruminant, Management

\section{Pragmatic Philosophy and Innovative Discussion}

Body condition scoring systems give fatness score to animals based on visual examination of fat depots in different body regions. The scale could be 1 to 5 or 1 to 10 depending on management criteria and animal type and breed. For instance, in a 5-score scale, BCS of 1 represents an overly thin or emaciated animal, and BCS of 5 describes an extremely fat or obese animal $[1,2]$. Apart from the fact that visual observations are prone to dramatic bias and inaccuracy depending on the perspective of different scorers, BCS does take into account only and merely the external fat and muscle tissues. Visual examination does in no circumstances take visceral or abdominal fats into consideration [3-6].

Recent studies provide compelling evidence that dairy cows with low and medium BCS may still have substantive amount of internal fats around splanchnic tissues $[5,6]$. This discovery suggests that cows that look normal as far as BCS is concerned (e.g., BCS of 3.5 for dry cows), could still carry a great quantity of adipose tissue in visceral sections that rapidly start to be mobilized towards liver upon parturition. Such a visceral adiposity and obesity categorizes an apparently normal dairy cow a serious case predisposed to complex disorders. The postpartum release of visceral depots introduces serious challenges to hepatic function and health [5-10]. Visceral fat stores are known to have substances that act as an alarm and induce metabolic shocks to liver and the entire animal [8]. Different adipokines and special proteins and peptides are interrelated with tissue necrosis and insulin resistance in non-ruminants [8-10]. Such inflammation messengers could lead metabolically challenged high-yielding ruminants to get trapped by different metabolic disorders such as fatty liver, ketosis, laminitis, metritis, mastitis, and weakened immunity [11].

Visceral fats are not visible in live herd animals on farm, and become evident and measurable only after slaughter. However, specific equations might be developed to predict visceral fat properties depending on several animal and management factors. Extensive large studies are required before such predictions can be developed accurately and reliably. Nevertheless, what is visible now is that visual inspection and scoring of ruminant metabolic state and body reserve condition is not an accurate indicator of the ruminant's real metabolic and health situation. Although this knowledge does not and should not undervalue the simplicity and in part practicality of BCS as a global assessment tool, complementary criteria are required to minimize major potential bias and error both locally and globally.

\section{Implication}

Based on the evidence-based philosophy elaborated on in this article, scoring of ruminant metabolic conditions based on only visual examination of external fat depots, as a practical management tool, could be neither accurate nor totally reliable. Complementary measures are needed to improve the accuracy of BCS as a pragmatic farm management implement.

\section{References}

1. Wildman EE, Jones GM, Wagner PE, Boman RL, Troutt HF, et al. (1982) A dairy cow body condition scoring system and its relationship to selected production characteristics. Journal of Dairy Science 65: 495-501.

2. Edmonson AJ, Lean IJ, Weaver LD, Farver T, Webster G (1989) A body condition scoring chart for Holstein dairy cows. Journal of dairy science 72: 68-78.

3. NRC (2001) National Research Council. Nutrient Requirements of Dairy Cattle (7thedn) National Acad Sci Washington, DC.

4. NRC (2000) National Research Council, Nutrient Requirements of Beef Cattle (7thedn) National Acad Sci Washington, DC.

5. Nikkhah A (2012) Visual Body Condition Score and Peripheral Metabolites and Insulin Responses to High and Low Dietary Energy Density in a Non-Pregnant Dry Cow Model. In Advances in Zoology Research. Owen P. Jenkins. Nova Science Publishers, New York, USA.

6. Nikkhah A (2012) Visceral Adiposity and Splanchnic Organ Mass in Non-Pregnant Dry Holstein Cows Offered Higher and Lower Energy Diets. In Advances in Zoology Research. Owen P. Jenkins. New York, USA.

7. Montague CT, O'Rahilly S (2000) The perils of portliness: causes and consequences of visceral adiposity. Diabetes 49: 883-888. 
Citation: Nikkhah A (2015) Visual Scoring of Ruminant Body Condition: Trapped in Inaccuracy. J Veterinar Sci Technol 6: e118. doi: 10.4172/2157-7579.1000e118

Page 2 of 2

8. Kern PA, Ranganathan S, Li C, Wood L, Ranganathan G (2001) Adipose tissue tumor necrosis factor and interleukin-6 expression in human obesity and insulin resistance. Am J Physiol Endocrinol Metab 280: 745-751.

9. Mokdad AH, Ford ES, Bowman BA, Dietz WH, Vinicor F, et al. (2003) Prevalence of obesity, diabetes, and obesity-related health risk factors, 2001. JAMA 289: 76-79.
10. Marette A (2003) Molecular mechanisms of inflammation in obesitylinked insulin resistance. Int J Obes Relat Metab Disord 27 Suppl 3: S46-48.

11. Nikkhah A (2015) Challenging Body Condition Score in Monitoring Dairy Cow Physiology and Health. Int J Dairy Sci Process 2: 12-13. 